\title{
IMPACTS OF INFORMATION AND COMMUNICATION TECHNOLOGY ON DEVELOPING QUALITY OF TEACHING
}

\author{
Avan AZIZ*, Palacky University Olomouc, Česká republika \\ Přijato: 14. 6. 2021 / Akceptováno: 19. 8. 2021 \\ Typ článku: Teoretická studie \\ DOI: $10.5507 /$ jtie.2021.010
}

\begin{abstract}
Information and communication technology (ICT) brings about magnificent improvement in the field of education. It also provides opportunities for innovations in the process of teaching and learning for the sake of achieving the desired learning in students. The approaches of teaching mainly transformed from the teacher-centred class into the student-centred one, with students actively engaging in learning. The teachers who use ICT are expected to effectively employ it in teaching and learning processes to improve not only the students' learning performance but also their own teaching proficiency. First, this study aims at demonstrating the effects of ICT on the development of teaching quality that could enable teachers to improve their pedagogical beliefs and practices. Second, it suggests the factors that result in progressing ICT teachers' teaching quality in educational settings. A qualitative methodology was adopted in this study, and the adopted analysis procedure includes a description of ICT, ICT and quality of teaching, the impacts of ICT on improving teaching quality (benefits of ICT in the teaching context), factors that result in advancing ICT and teaching quality in the educational settings and conclusions. This paper has drawn on educational research and emerging new practices of ICT in teaching and learning processes to investigate the impacts of ICT on developing quality of teaching.
\end{abstract}

Key words: ICT, Developing Quality of Teaching

\section{VLIV INFORMAČNÍCH A KOMUNIKAČNÍCH TECHNOLOGIÍ NA ZVÝŠENÍ KVALITY VÝUKY}

\begin{abstract}
Abstrakt: Informační a komunikační technologie (ICT) přináší v oblasti vzdělávání mnoho výhod. Poskytují príležitosti pro inovace v procesu výuky a učení za účelem dosažení požadovaných vzdělávacích výsledkủ. Prístupy k výuce se čím dál více proměňují, konkrétně ze zaměření na učitele, směrem k orientaci na žáka, přičemž ti se aktivněji zapojují do procesu učení. Od učitelů, kteří využívají ICT, se očekává, že je
\end{abstract}


efektivně využijí v rámci výuky za účelem zlepšení nejen vzdělávacích výsledků, ale také k rozvoji vlastních učitelských kompetencí. Tato studie si klade za cíl prezentovat vlivy ICT na zvýšení kvality výuky. Dále navrhuje faktory, které vedou ke zlepšení kvality př́pravy učitelů. $V$ této studii byla užita kvalitativní metodologie. Analýza obsahuje popis ICT, vztah ICT a kvality výuky, dopady ICT na zlepšování kvality výuky (přínosy ICT v kontextu výuky), faktory, které vedou k rozvoji ICT a kvality výuky ve vzdělávacích prostředích a závěrech.

Klíčová slova: ICT, kvalita, výuka

*Autor pro korespondenci: avan.aziz01@upol.cz

\section{Introduction}

Serious attempts have been made in the process of education to improve the quality of teaching and learning to achieve the desired learning in students. One of the attempts that helps us to get close to the target is the integration of information and communication technology (ICT) in teaching and learning processes. ICT has clearly enhanced the opportunity for teachers to easily access information, inspiring new betterment in teaching, and makes it easy for everyone to contact each other anytime and anywhere they want. Today, ICT is generally used in the classroom to support teaching and learning, and several studies have declared its effectiveness in improving students' learning performances.

Therefore, incorporating ICT in the classroom requires well-equipped technoteachers ${ }^{1}$. For this purpose, teachers need to develop their profession through participating in preparation and training programmes related to ICT use. The programmes should not only provide the teachers with isolated courses in educational technology but also offer clear insight about the implementation of ICT in the teaching content and pedagogy (Charalambos \& Glass, 2007). Thus, it can be inferred that the capability to afford ICT tools and educational equipment in the educational setting is not only enough for achieving the best learning in students but also the presence of professional techno-teachers will make the learning process complete and promising.

1 "The techno-teacher is one who integrates the content with technology in the classroom" (Kaur, 2015, p. 8). 


\section{What is ICT?}

There are various definitions of ICT in educational settings. According to UNESCO ICTs are "forms of technology that are used to transmit, process, store, create, display, share or exchange information by electronic means" (UNESCO, 2002, p. 10) (see Figure 1). In line with Kaur (2015), ICTs encompass the "hardware, software, networks, and media for collection, storage, processing, transmission and presentation of information (voice, data, text, images), as well as related services" (p. 8). Further, ICT in education supplies technology that underpins, advances and stimulates the delivery of information from a teacher-directed to a student-centred model (Kaur, 2015). Evidently, the use of ICT in education adds value to teaching and learning through optimising the efficiency of learning. It also adds a dimension to learning that was not previously available. Since the integration of ICT in educational institutes and schools, students can access a technology-based learning atmosphere that is more encouraging and engaging than in a traditional learning environment (Bose, 2017).

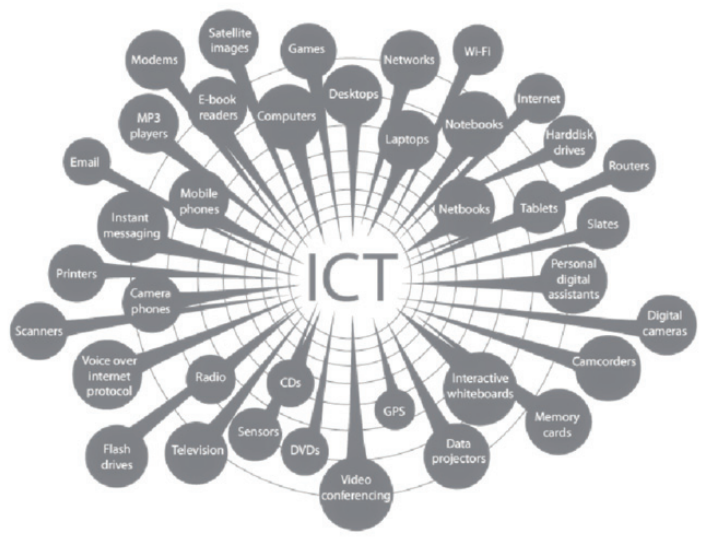

Fig. 1: ICT Devices from UNESCO (2010) retrieved from Kareem (2017, p.11)

\section{ICT and Teaching Quality}

Effective teachers always look for new and best modes of teaching to engage their students during the learning sessions. One of the highly potent ways that appeal 
to the students' attention to learning is using technological tools and programmes in class or outside of class. It does not matter how large or small the investment is; the only significant aspect here is how much the investment is able to produce effective impacts on the students' learning. Accordingly, there is a need for skilful and well-qualified teachers to be the right teacher to provide the right education to the right students to enhance the students' learning. According to Attfield (2012), the "quality of teaching is the foremost determinant of the quality of students' learning" ( p. 1). "Teachers tend to teach as they were taught. If teachers are expected to teach using ICT", they should be enrolled in training and preparation programmes regarding the ways of using and incorporating ICT in the teaching process. Additionally, as it has been mentioned previously, the programmes should not simply offer a theoretical overview about the use of ICT; rather, they should provide the opportunity to the participants (teachers) to apply what they learn in the training sessions so as to clearly and precisely obtain enough knowledge regarding ICT in the teaching content and pedagogy (Charalambos \& Glass, 2007). Law (2008) states the following:

Teachers still need to be professionally ready and developed in regard to their technological training. They have to welcome the orientation and motivation that enables educators to enter a professional network of innovators. Then they can produce pedagogical innovation enhancing their original goal, to educate in the 21st century (as cited in Kareem, 2017, pp.33-35).

The use of ICT provides an online learning opportunity for the teachers to innovate, reform and improve their teaching quality. For instance, using ICT, teachers can create or participate in communities of practice; they "are groups of individuals bound by what they do together, anything from engaging in informal negotiations to solving problems, and by what they have learned through their mutual engagement in these activities" (Charalambos \& Glass, 2007, p. 90). The abovementioned online practice communities offer opportunities for both formal and informal professional development for teachers. Another example of an ICT-related model that eases the teacher's teaching quality betterment is Supporting Teachers with Anywhere/Anytime Resources (STAR)-Online. STAR-Online represents a form practice communities; this model is designed for maintaining education and the teachers' proficiency growth. Through this model, teachers are able to access mentors, colleagues and resources by a web-based virtual teaching and learning community (VTLC) system, which dispenses interactive, self-paced 
and collaborative enhancement. The VTLC online model enables teachers to boost knowledge and obtain ICT skills in the application of educational technology. VTLC helps them to develop lesson plans, share them with experts and peers, get feedback and remark on others' work. In addition, teachers are able to partake in "quality online training modules, access resources, build an online portfolio, and collaborate with other teachers" (Charalambos \& Glass, 2007, p. 91) across specific parts of the world such as the United States. Thus, ICT not only supports students' learning but also can be made use of for the teachers' professional development. It assists teachers to learn up-to-date methods of approaching teaching and learning. It provides multiple forms of interaction and designs of learning contexts that underpin the teachers' proficiency development, collaboration, discussion, and solving the pitfalls they face during their teaching (Charalambos \& Glass, 2007).

\section{Analysing the Impacts of ICT on Developing Quality of Teaching.}

\subsection{Benefits of ICT in Teaching Context}

There is a significant amount of research that states that besides aiding students to learn, ICT also inspires and encourages teachers to teach effectively. According to Cox et al. (1999), ICT helps teachers both in their personal work and in their teaching. In this context, ICT nurtures teachers in "making the lessons more interesting, easier, more fun for them and their learners, more diverse, more motivating for the students and more enjoyable" (Mumtaz, 2000, p. 338). Further, in terms of personal work, ICT advances the presentation of materials, allows greater access to computers for their personal use, offers more confidence and power to the teacher in the educational setting, contributes more prestige to the teacher, makes the teachers' administration more well organised and effectual, dispenses professional support through the Internet and enable teachers to have more selfassurance in their work (Mumtaz, 2000).

Moreover, ICT can facilitate teachers when they present lessons, prepare a lesson plan and assess student learning. To illustrate, Njoku reports the helpfulness and usefulness of both learning content management system (LCMS) and learning management system (LMS) as well as their authoring tools for teachers. The aforementioned tools are computer programmes used for generating contents for LMS and LCMS. Using LCMS may help the teacher to "create new content from gathering other content of other sources, manage and edit e-Learning content, 
prepare the schedule of the courses and identify strategies of learning, administer students effectively, and make communication feasible through e-mail, chatting and forum" (Kareem, 2017, p. 32). It is not necessary for the teachers to be proficient at using some of the tools to create the content they desire or need to post. This tool is able to export content as self-contained web pages or as content packages (Kareem, 2017).

Furthermore, there is a positive and meaningful relationship between the use of ICT and classroom management. According to Sabanci et al. (2014), ICT supplies and increases the positive atmosphere in classroom; on one hand, it reduces group interaction and rapport, but on the other hand, it increases student-teacher and student-technology interaction and enhances the students' participation in classroom activities that consequently raises their comprehension; in such a class, teachers are free of the stress which may be caused by the necessity of completing the programme considered in the curriculum. It allows teachers to eliminate unnecessary details and concentrate on the core subject, and it aids teachers to use class time effectively for classroom activities such as preparing a lesson, warming up for a lesson and transitioning from one activity to another and giving feedback. Further, ICT provides teachers with the time and opportunities to implement new teaching strategies and methods, assess the learners' performance more effectually and observe and communicate with each learner individually, and it offers teachers more data to achieve the objectives of the lesson and schedule the new steps for learning.

Additionally, there are some specific benefits that teachers can find when they utilise ICTs; for instance, during teaching in classes, teachers might need more methods and instructional tools to explain the lesson. Some teachers encounter hard times when they need to demonstrate graphs, diagrams, and visuals and play audio files while practising the traditional ways of teaching; however, using ICTs helps evade such difficulties (Kareem, 2017). In that respect, Njọụ states the importance of Microsoft PowerPoint in higher education institutions for presenting presentations. Accordingly, using Microsoft PowerPoint, teachers can manage teaching significantly large classes during lecture sessions by presentations. Moreover, sometimes teachers have additional responsibilities or jobs other than teaching, which may require them to attend an administrative meeting, conference, workshop or any other academic meeting; at the same time, they should not miss their teaching session. In this case, ICT can be a highly helpful and economical factor for these teachers; for instance, teacher can teach the students 
and engage them in the lesson through video conferencing the without worrying about missing the teaching session (2015). Thus, ICT underpins changing the way students learn and formulates the quality of instruction of the teachers as well.

\subsection{Factors that Result in Advancing ICT Teaching Quality}

At present, many efforts are being made globally to formulate the whole education system through integrating ICT, generally, in the teaching and learning process and, particularly, in teacher training programmes. The author believes that the most cardinal aspect that the government needs to work on is expanding the factors that stimulate teachers to have a tendency to improve their ICT competence and literacy, which would result in optimising both their teaching proficiency and the students' learning performance. In this section, some of the factors that advance the ICT teachers' quality of teaching are discussed.

Teachers have a great impact on the effectiveness of the process of teaching and learning; therefore, they will have a fundamental influence on the successful adoption and application of ICT in this regard as well. "It is their acceptance, attitudes, and intention to use ICT that determine the quality of its integration into the school system and the success or failure of its use as a learning and a teaching tool" Alshmrany \& Wilkinson, 2017, p. 143). Hence, it is necessary that the teachers have a positive intention to use ICT for their daily activities; otherwise, the process of ICT integration will not be useful and promising (Alshmrany \& Wilkinson, 2017). Subsequently, to help the teachers' performance expectancy ${ }^{2}$ positively improve, it is necessary to get them to familiarise with the effects of ICTs through seminars and workshops. Based on the studies and ICT educators' experiences, the positive impacts of ICT regarding teaching and learning, including how both can be made easier and successful if the teacher has enough competence in ICT, should be demonstrated. Then, offering them the opportunities for participating in ICT training courses would also encourage teachers to apply what they have learned in the classroom sessions at their schools. Later, they, could share their experience with other trainees and educators to ascertain the strong and weak points of their application and how to improve the weak points. Encountering the ICT use by the teachers and helping them how to use technological tools and

\footnotetext{
2 "Is the degree to which an individual believes that using the system will help him or her to attain gains in job performance" (Alshmrany \& Wilkinson, 2017, p. 145).
} 
programmes efficiently make the teachers have a positive expectancy and perception of the usefulness of using technology because they learn how to use it in school activities, administrative and teaching processes. As a result, if the teachers believe that ICT is beneficial and expect that their performance will progress with access to ICT, they will also formulate a positive intention to practice technology in their classes (Alshmrany \& Wilkinson, 2017).

Moreover, "Teachers should also know the right attitudes and values, besides being proficient in skills related to teaching" (Bhattacharjee \& Deb, 2016, p. 3). Therefore, teachers should work on having enough ICT knowledge and using, as a learner, the same in in-service training programmes that facilitate enhancing their quality of teaching. Simultaneously, it would advance the students' learning. It is clear that one of the basic demands of the training programme is that it should assist and support the trainee to master the basic skills and competencies of a good teacher (Bhattacharjee \& Deb, 2016). The purpose of allocating sufficient opportunities for the teachers to raise their ICT literacy is to help the teachers be able to integrate the use of basic ICT tools and programmes into the "standard school curriculum, pedagogy, and classroom structures". According to Leach and Moon (2002) teachers receiving enough knowledge and training would inspire them to know how, where, when and even when not to use technology for classroom activities, management tasks, obtaining supplementary materials and also for pedagogical knowledge in support of their own professional betterment (as cited in Hennessy et al., 2010, p.72). So, we can get to the point that a comprehensive and thorough ICT teacher training program is required in order for instructors to become familiar with the variety of uses and potential benefits of ICT in order to improve their teaching quality.

After teachers receive adequate training and competency in ICT use, they need to have a supportive environment to get the most from using ICT in their teaching. If the teachers realise that they need to put in a lot of effort to use the technology, they would be demotivated and their negative effort expectancy would discourage them for not using it because of much of the hindrances. Thus, even if the teachers' quality has been improved, if they are not supported to apply what they learned in their teaching, it would be as if no effort has been made. The government can avoid the teachers' negative effort expectancy through providing

3 "The amount of effort the users expect it will take to use a technology" (Alshmrany \& Wilkinson, 2017, p. 145). 
enough access to technological resources such as computers, updated software and hardware, etc. for both teachers and students and facilitate them to afford good technical support in the educational setting. Accordingly, the teachers will have a positive effort expectancy, and they will find it easy to use ICT in their daily school activities. Additionally, they will be more encouraged to consistently develop their ICT use and teaching quality (Alshmrany \& Wilkinson, 2017). Further, several studies have reported that despite having many teachers who are competent and confident in using ICTs in the classroom, they still make little use of the technologies because of a lack of time (Kaur, 2015, p.11). For these purposes, teachers need to be familiarised with the techniques of how to deal with the shortage of time in classes. For instance, when the teacher knows that there is insufficient time to do or complete an activity on the computer in the class, she/ he can give it as an assignment to be completed at the library, home or anywhere that is convenient to the students.

Last but not least, another supporting factor for the teachers is designing the curriculum that should be for both teachers and students to enrich their knowledge and skill in ICT. Designing ICT literacy as an area of the curriculum makes both teaching and learning processes easy and joyful. ICT literacy topics entail the following: "basic concepts of ICT, using computers and managing files, word processing, spreadsheets, databases, creating presentations, finding information and communicating with ICT, social and ethical issues, and jobs using ICT" (Adu, 2013 , p. 3). In addition to providing enough knowledge and training for teachers, as given in the aforementioned factors, it would help them know how ICT is applied in their own subject area such languages, art, mathematics, social sciences, natural sciences and so on. Some of the topics that teachers need to get familiar with are as follows: "measurement, modeling and simulation, robots and feedback devices, statistics, creating graphics, spreadsheet design, and database design" (Adu, 2013, p. 3). The third area is the integration of ICT across the curriculum to provide opportunities for teachers and students to know how to apply ICT within their subject area and use it in the real-world projects and solve real problems (Adu, 2013). Finally, ICT and education specialisation is one of the highly potent areas that the ministry of education should take into consideration. This area should be dedicated to those learners who desire to study in a field of ICT and education. Specialised ICT teachers would be a supportive educator for those teachers who do not have enough knowledge of ICT use. These teachers through their studies, training programmes, workshops and experiences can maintain 
the other teachers' positive expectancy toward ICT use, motivate them to keep on their professional development, empower them to address the ICT challenges they confront in their everyday teaching and help them meet needs for improving their teaching quality.

\section{Conclusion}

ICT has played a supportive role in the process of education; it has positively changed the way students are learning, and it continues to develop the teachers' quality of instruction. The capability to afford ICT tools and educational equipment in the educational setting will not only be enough for achieving the best learning in students but also the presence of professional techno-teachers will make the learning process complete and promising. By the same token, Ministry of Education need to pay more attention to the ICT needs at schools and universities and work on improving those factors that have effective impacts on developing the teachers' teaching proficiency using ICT.

\section{References}

Adu, E. O. (2013). Information communication technology (ICT) and curriculum development: The challenges for education for sustainable development.

Alshmrany, S., \& Wilkinson, B. (2017). Factors influencing the adoption of ICT by teachers in primary schools in Saudi Arabia. Teachers' perspectives of the integration of ICT in primary education. International Journal of Advanced Computer Science and Applications, 8(12).

Attfield, R. (2012). Improving the quality of teaching. National College for school Leadership.

Bhattacharjee, B., \& Deb, K. (2016). Role of ICT in $21^{\text {st }}$ century's teacher education. International Journal of Education and Information Studies, 6(1), 1-6.

Bose, R. (2017). Effectiveness of ICT in education.

Charalambos, V., \& Glass, G. V. (2007). Teacher professional development and ICT: Strategies and Models. Yearbook of the National Society for the Study of Education, 106(2), 87-102.

Kareem, N. N. (2017). The importance of using information communication technology for learning and teaching the English language in Kurdistan of Iraq.

Kaur, N. (2015). Using ICT in empowering teachers for quality education. International Journal of Scientific Research Engineering \& Technology (IJSRET) ISSN: 2278-0882.

Mumtaz, S. (2000). Factors affecting teachers' use of information and communications technology: A review of the literature. Technology, Pedagogy and Education, 9(3), 319-342.

Njoku, C. P. U. (2015). Information and communication technologies to raise quality of teaching and learning in higher education institutions. The International Journal of Education and Development using Information and Communication Technology, 11(1), 122-147.

Sabanc1, A., Ozyildirim, G., \& Imsir, R. (2014). The effect of ICT usage on the classroom management: A case study in language teaching. International Review of Social Sciences and Humanities, 7(1), 232-245. 
UNESCO 2002, Information and Communication Technology in Education: A Curriculum for Schools and Programme of Teacher Development. Paris: UNESCO. 